\title{
FUZZY MODELING OF THE EFFECTS OF IRRIGATION AND WATER SALINITY IN HARVEST POINT OF TOMATO CROP. PART II: APPLICATION AND INTERPRETATION
}

\author{
Daniel dos S. Viais Netoํ, Camila P. Cremasco², Deyver Bordin ${ }^{3}$, Fernando F. Putti², \\ Josué F. Silva Junior ${ }^{4}$, Luís R. A. Gabriel Filho ${ }^{5^{*}}$
}

\author{
${ }^{5 *}$ Corresponding author. São Paulo State University (UNESP), School of Sciences and Engineering/ Tupã - SP, Brasil. \\ E-mail: gabriel.filho@unesp.br | ORCID ID: http://orcid.org/0000-0002-7269-2806
}

\section{KEYWORDS}

fuzzy logic, hydro potential, drought, salt stress.

\begin{abstract}
Tomato, the most popular greenery, is characterized by being a demanding crop in water and when in prolonged and severe drought, has limitations in its growth and reduction in productivity. In addition, this vegetable is affected by excess salinity in the water, which causes leaf wilting, apex and leaf edges burn until their death. Such effects generally are studied using statistical analysis, but there are mathematical theories that allow finer adjustments, highlighting among them, the fuzzy logic. The objective of this study was to evaluate the effects on the growth and yield of hybrid tomato from different water tensions in the soil and different salinity doses in the irrigation at 120 days after sowing using fuzzy modeling. It was used data from an experiment that was conducted in the experimental area at the School of Agriculture of São Paulo State University (UNESP) in Botucatu-SP. The input variables of the fuzzy systems were irrigation and salinity, while the output variables elected were the biometric analysis and productivity that showed statistically significant differences. Analyses of the effects of irrigation and salinity were performed by means of three-dimensional graphics and the output variables contour maps. The variables studied here showed higher values, with exception of plant height for treatment with irrigation in field capacity and water salinity zero.
\end{abstract}

\section{INTRODUCTION}

The production, processing and consumption of Solanum lycopersicum L. fruits are increasing worldwide, demanding technologies to improve tomato growth efficiency (Mariz-Ponte et al., 2018). The grow crop is water demanding, needing to be managed that results which provides higher yield and better utilization of water resources (Silva et al., 2013a). In addition, the tomato is severely restricted to high levels of electrical conductivity for use in irrigation (Borges et al., 2015).

The tomato is a demanding management crop, among which irrigation exerts a strong influence on fruit production and quality since it is considered sensitive to water deficit (Santana et al., 2010). Other occurrences due to lack of water are "crack fruits, occurrence of hollow fruit, flowers fall, besides the reduction in the establishment of the fruits, and such oscillations effects more severe if the crop is installed in a relatively saline environment" (Medeiros, 2010).

According to Duarte et al. (2007), the term salinity of the water and soil is directly related to the level of salts contained therein and when in high amounts in the root zone can cause low water availability for the plants, thereby reducing, in some cases the production.

The regression analysis, commonly used for the evaluation of agronomic experiments often does not express intermediate values, so the fuzzy modeling allows more sensitivity extract values before unobserved (Putti, 2015). There are computational techniques that allow finer adjustments, and one of these techniques is the fuzzy logic, introduced in scientific circles by Zadeh (1965).

In agronomy, various applications that make up the different uses of this technique are found, for example, in developing a support system for irrigation and water conservation in agriculture (Giusti \& Marsili-Libelli, 2015), in support of the management of orchid species

\footnotetext{
${ }^{1}$ São Paulo State Faculty of Technology (FATEC)/ Presidente Prudente - SP, Brasil.

${ }^{2}$ São Paulo State University (UNESP), School of Sciences and Engineering/ Tupã - SP, Brasil.

${ }^{3}$ São Paulo State University (UNESP), School of Agriculture/ Botucatu - SP, Brasil.

${ }^{4}$ Federal University of the Triângulo Mineiro/ Iturama - MG, Brasil.

Received in: 7-11-2018
}

Accepted in: 3-26-2019 
(Putti et al., 2014), in the evaluation of the features of agricultural land (Kurtener \& Sukhanov, 2014) and in the evaluation of fertilization with composted sewage sludge and irrigation with drinking water and fertigation with wastewater in wheat crop (Putti et al., 2017).

Thus, it is justified the study of the producer practical issues, such as the management of irrigation and salinity. This fact gains greater amplitude in tomato crop to be sensitive to drought conditions and the osmotic process caused by salinization of water. Thus, there is a need for studies that show the effects of this management in this crop, which is usually only done in some fixed levels of irrigation and salinity. Seeking the determination of results in several other points not seen in experiments, it is proposed the use of the fuzzy theory, allowing such extrapolation.

It should be noted the importance of this new analysis of the results using three-dimensional surfaces and contour maps across the everyday use using only the results of statistical analysis (ANOVA to compare means, in general, by Tukey test or others). The present modeling proposal enables the analysis of the responses of the tomato crop in the two sources of variation together (water tension in soil and salinity doses in irrigation), also showing the calculation by the proposed method of all intermediate values of such levels.
Thus, the objective of this study was to evaluate the effects on the growth and productivity of the hybrid tomato (Licopersicum esculentum) in different soil water tensions and water salinity doses in irrigation at 120 days after sowing using the fuzzy modeling.

\section{MATERIAL AND METHODS}

\section{Description of the experiment}

The experimental data used for the fuzzy modeling of this study were statistically analyzed in Silva Junior (2012) and used in the preparation of the fuzzy modeling Part I of this study. As described in such study, the experiment was carried out between June and October, in a protected environment installed in an area with an average altitude of $786 \mathrm{~m}$, latitude $22^{\circ} 51^{\prime} 03$ " South, longitude $48^{\circ} 25^{\prime} 37^{\prime \prime}$ West and situated in the Department of Rural Engineering of the School of Agriculture of São Paulo State University (UNESP) in Botucatu-SP.

The environment used (Figure 1) was a high tunnel type greenhouse, with dimensions of $27 \mathrm{~m}$ in length; $7 \mathrm{~m}$ wide; $1.7 \mathrm{~m}$ height and $3 \mathrm{~m}$ high in the center. Its structure was shaped in arches made from galvanized pipe and coating of polyethylene additive transparent film, with 150 $\mathrm{mm}$ thick.

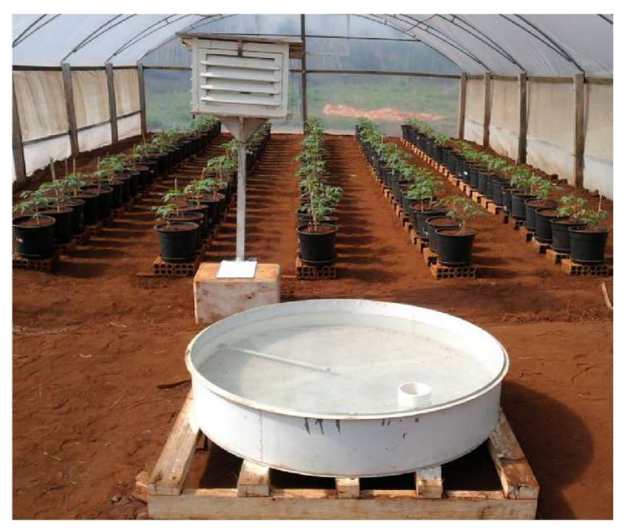

FIGURE 1. Experimental area in greenhouse of FCA, UNESP, Botucatu Campus-SP, and equipment of meteorological measurements class A tank, shelter with digital thermo-hygrometer and spacing used $(1.0 \times 0.4 \mathrm{~m})$.

Source: Silva Junior (2012).

On the greenhouse sides it was installed a "shading" screen with $30 \%$ of shading, in order to trap insects and animals. The greenhouse had guidance in the North / South direction in length, perpendicular to the sun trajectory.

The soil was characterized Oxisol Distroferric of medium texture and was collected from layer of $0-0.20 \mathrm{~m}$ depth. This was torn off and sieved and then dried in air to achieve $4 \%$ moisture content. The pots had capacity of 15 $\mathrm{dm}^{3}$ and were filled so that each container contained $13 \mathrm{~kg}$ of soil.

The liming and fertilization of planting and coverage were based on soil analysis, following the recommendation contained in the Technical Bulletin 100 (Trani \& Raij, 1997). The variety of tomato used was cv. Katia. The seedlings were prepared by the Department of Horticulture and transplanted to pots 45 days after sowing. The leading was a single rod, wherein the plant spacing was $1 \mathrm{~m}$ between rows and $0.6 \mathrm{~m}$ between plants. The staking was held individually with narrow ribbon, eliminating all the shoots from the leaves axils.

As also described in Part I of this study, irrigation management has been established to supply water to the crop in three conditions of soil matrix potentials $(\Psi=-60$, -30 and $-10 \mathrm{kPa})$. Furthermore, the water used for irrigation had electrical conductivity (EC) of 0.08 (no salt added) and the concentrations of 3 and $5 \mathrm{dS} \mathrm{m}^{-1}$. Thus, we used three salinity doses in the experiment.

To determine the dilution of sodium chloride $(\mathrm{NaCl})$ in the water, it was used standard curve salinity proposed by Silva Junior (2012), wherein the electrical conductivity $(\mathrm{EC})$ is expressed by the equation $E C=$ $0.00874 \mathrm{NaCL}\left(m L L^{-1}\right)+0.284$.

The calculation of water to be applied in each treatment occurred by reading twenty-seven tensiometers installed at $0.15 \mathrm{~m}$ depth, with three tensiometers per treatment, moreover, irrigation occurred when the average matric potential in the soil, taken from " $\mathrm{A}$ " horizon layer 
( $0-20 \mathrm{~cm}$ depth) used in the pots, was in the range of -30 or $-60 \mathrm{kPa}$ and, one of the treatments with no water stress was maintained with constant water content in the soil (gravimetric humidity $0.286 \mathrm{~g} \mathrm{~g}^{-1}$ ) irrigating by field capacity (FC).

To obtain the water content in the soil, relationships of the volumetric water content with tension which the water is retained were used and are shown in Table 1. With such data it was possible to prepare a water retention curve in the soil by nonlinear methods existing in the literature, being chosen the Van Genuchten (1980) method for the determination of such curve, thus enabling to find the value of the soil water content for the water potential $60 \mathrm{kPa}$.

TABLE 1. Relationship between potential and water content in the soil used in the experiment (gravimetric humidity - GH), for the layer from $0-0.20 \mathrm{~m}$.

\begin{tabular}{cc}
\hline$\Psi_{\mathrm{t}}(-\mathrm{kPa})$ & $\mathrm{GH}\left(\mathrm{g} \mathrm{g}^{-1}\right)$ \\
\hline 10 & 0.286 \\
30 & 0.244 \\
50 & 0.232 \\
100 & 0.211 \\
300 & 0.199 \\
500 & 0.198 \\
1500 & 0.194 \\
\hline
\end{tabular}

Source: Silva Junior (2012) (Adapted).

The biometric and yield parameters of tomato at 120 days after sowing, and also used in Part I of this study were: plant height $(\mathrm{cm})$, stem diameter $(\mathrm{cm})$, leaf area $\left(\mathrm{cm}^{2}\right)$ green biomass $(\mathrm{g})$ dry weight $(\mathrm{g})$, fruit number (units), average fruit weight (g) and percentage of disabled fruits $(\%)$.

According to Silva Junior (2012), the plant height of the experiment in study corresponded to the distance between the base, from the ground, and the apex of the plant; and stem diameter was determined in the basal region of the plant, close to the ground. Also, by the same author, leaf area was calculated using an estimate made with the dry weight of the leaf, for that were taken from younger leaf leaflets fully expanded ten discs, $8 \mathrm{~mm}$ in diameter, they were kept in drying oven with forced circulation air at $65^{\circ} \mathrm{C}$ for $24 \mathrm{~h}$ and finally it was considered the average of the masses of the ten discs equal to an area of $0.5 \mathrm{~cm}^{2}$.

The calculation of both the green as the dry biomass, in the same experiment corresponded to the sum of the masses of the leaflets, petioles, stems and clusters. Finally, the percentage of disabled fruits was calculated in relation to fruits that present apical rot.

The experimental design was completely randomized in a double factorial with three replications, three water tension in the soil $(-60,-30$ and $-10 \mathrm{kPa})$ and three salinity levels $\left(0.08,3\right.$ and $\left.5 \mathrm{dS} \mathrm{m}^{-1}\right)$.

\section{Fuzzy modeling}

The fuzzy modeling used was characterized methodologically in Part I of this study, to establish a mathematical model of the effects on the biometric and productivity variables at the harvest point of the tomato crop, which occurred 120 days after sowing (DAS). Some characteristics of such methodology, related to the way of creating pertinence functions or basic rules were similar to those made and implemented in Cremasco et al. (2010), Gabriel Filho et al. $(2011,2015,2016)$, Pereira et al. (2008) and Putti et al. (2014).

The model input variables were related to different water stresses in the soil (irrigation) and different salinity doses in the irrigation (salinity) along the tomato cycle, while the outputs were the biometric and yield parameters of the tomato crop (Figure 2).

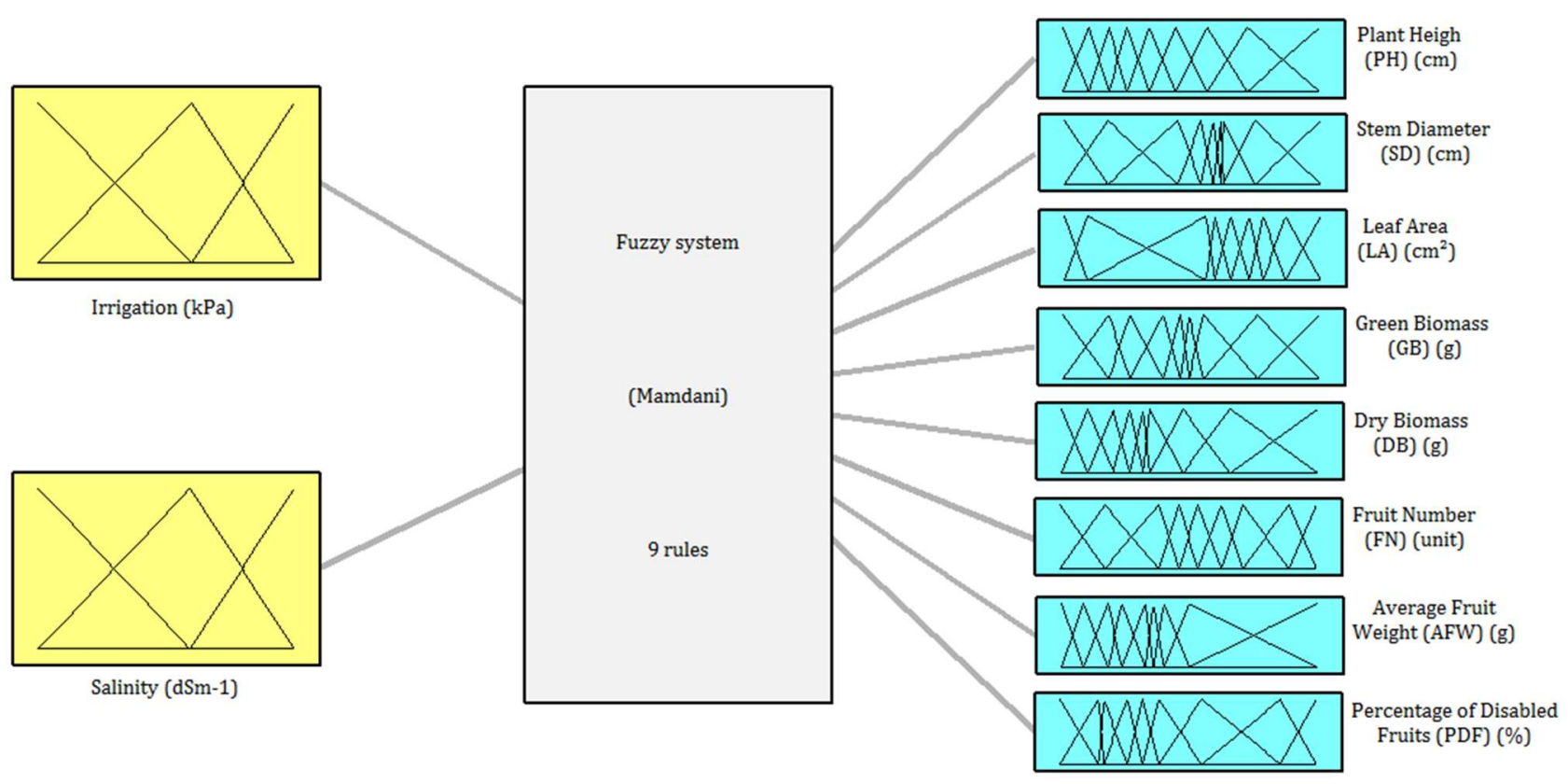

FIGURE 2. Fuzzy Rule-Based Systems (FRBS) of tomato evaluation with two input variables (Irrigation and Salinity), 8 output variables (biometric and productivity variables).

Source: Part I of this study. 
It is noteworthy that all the above output variables were chosen because they present significant differences among the water tension in the soil and / or salinity doses irrigation 120 days after sowing and / or interactions among these factors, according to Silva Junior (2012), with a level of significance $\alpha=5 \%$ (Table 2). In addition, for some agronomic discussions of the results, we calculated the value of $\mathrm{R}^{2}$ determination coefficient and their respective $\mathrm{p}$-value.

TABLE 2. Squares Mean values (SM) and coefficient of variation (CV) obtained from analysis of variance for possible output variables FRBS.

\begin{tabular}{c|cccccccc}
\hline Variation factor & \multicolumn{9}{|c}{ SM } \\
\cline { 2 - 8 } & PH & SD & LA & GB & DB & NF & AFW & PDF \\
\hline Irrigation $(-\mathrm{kPa})$ & $853.00^{*}$ & $0.07^{*}$ & $3455.69^{*}$ & $3738.51^{*}$ & $56.14^{*}$ & $117.81^{*}$ & $326.23^{*}$ & $2912.87^{*}$ \\
Salinity $\left(\mathrm{dS} . \mathrm{m}^{-1}\right)$ & 59.24 & $0.08^{*}$ & $1159.93^{*}$ & $1508.12^{*}$ & $157.42^{*}$ & $22.23^{*}$ & $323.88^{*}$ & 1643.07 \\
Irrigation $\times$ Salinity & 2.16 & $0.09^{*}$ & $848.99^{*}$ & 10.73 & 33.20 & $9.78^{*}$ & 77.40 & $2286.74^{*}$ \\
\hline CV $(\%)$ & 12.85 & 6.68 & 24.17 & 12.03 & 16.14 & 11.97 & 11.62 & 19.99 \\
\hline
\end{tabular}

Legend: $\left(^{*}\right)$ significant by $\mathrm{F}$ test at $5 \%$ probability of error; Variations factors: plant height $(\mathrm{PH}, \mathrm{cm})$, stem diameter $(\mathrm{SD}$, cm), leaf area $(\mathrm{LA}, \mathrm{cm} 2)$, green biomass (GB, g) dry biomass (DB, g), fruit number (FN, units), average fruit weight (AFW, g) and percentage of disabled fruits (PDF, \%).

Source: Silva Junior (2012) (adapted)

\section{Inference and defuzzyfication method and softwares used}

The inference method used in this study was the Mamdani method and the Gravity Center Method was adopted for the defuzzyfication, in which the value of the output linguistic variable inferred by the fuzzy rules are translated into real value.

It was necessary the Matlab ${ }^{\circledR}$ software for the use of FRBS, which the School of Sciences and Engineering of São Paulo State University (UNESP) in Tupã-SP has the license to use. Specifically, the Fuzzy Logic Toolbox tool the same software was used for the preparation of the three-dimensional graphics and contour maps.

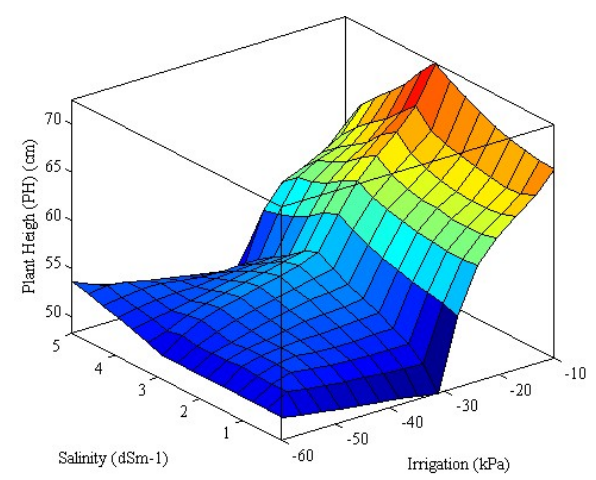

(a)

\section{RESULTS AND DISCUSSION}

Using the methods of inference and defuzzyfication adopted the three-dimensional graphics and their contour maps of the output variables were obtained as the system solution.

With regard to plant height, it was found from the fuzzy modeling that the highest value was obtained when the tomato crop was subjected to water pressure in the soil at $-10 \mathrm{kPa}$ and the salinity dose in the irrigation of $3 \mathrm{dS}$ $\mathrm{m}^{-1}$. The lowest value was for water tension in the soil of $30 \mathrm{kPa}$ and salinity dose in the irrigation of $0.08 \mathrm{dS} \mathrm{m}^{-1}$ (Figure 3).

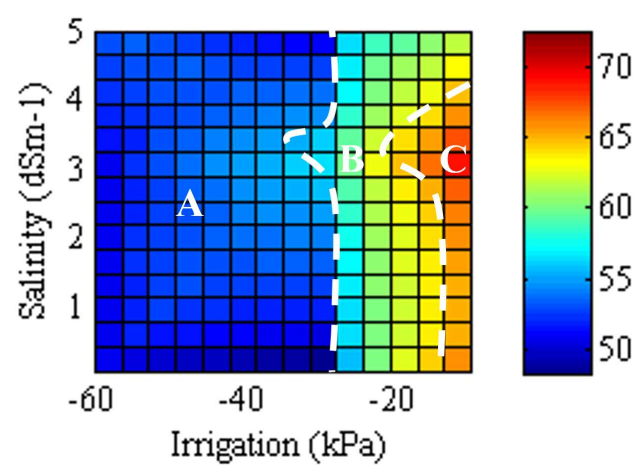

(b)

FIGURE 3. Plant height $(\mathrm{PH})$ (in $\mathrm{cm}$ ) for the tomato crop irrigated under water tensions (between -60 and $-10 \mathrm{kPa}$ ) and salinity levels of irrigation (between 0.08 and $5 \mathrm{dS} \mathrm{m}^{-1}$ ). (a) Three-dimensional graph and (b) Contour map.

From the three-dimensional graph (Figure 3a) the contour map could be drawn (Figure 3b). In region A was verified that among the water tensions in the soil -60 to -30 $\mathrm{kPa}$ there was no effect on plant height, but at tensions above $-30 \mathrm{kPa}$ (Region $\mathrm{B}$ and $\mathrm{C}$ ), it was found increases in plant height compared to Region $\mathrm{A}$. the highest values of this variable were obtained in the treatments belonging to region $\mathrm{C}$, where it was held $\mathrm{FC}$ irrigation.

This effect was derived in the region of low water availability in the soil, which directly affects the relationship plant-soil, in which water is strongly held in the ground, and thus affecting the physiological and photosynthetic processes (Taiz \& Zaiger, 2013). Under these conditions, it occurs the closing of the leaf stomata and reduction in transpiration, and consequently, reduction of water and nutrients input by plants resulting in reduced plant growth (Lima et al., 2015).
According to Silva Junior (2012), water tensions in the soil of $-60 \mathrm{kPa}$ and $-30 \mathrm{kPa}$ showed 26.7 and $24.1 \%$ reductions in plant height, respectively, when compared with the tension of $-10 \mathrm{kPa}$ for any salinity dose in the water. Since Soares et al. (2011) obtained an increase in the height of tomato when irrigated with depths of up to $120 \%$ of evapotranspiration (ETo). Regarding the salinity of the water, there was no effect of dose on plant height, contrary to what was observed by Gomes et al. (2011) and Guedes et al. (2015), that by experiments with other tomato cultivars inferred that a reduction in plant height with increasing salinity has happened.

It was found in the diameter of the stem analysis, by means of fuzzy modeling that the highest value occurred between $-20 \mathrm{kPa}$ to $-10 \mathrm{kPa}$ and $0.08 \mathrm{dS} \mathrm{m}^{-1}$. The lowest value was found for the water tension in the soil of $-10 \mathrm{kPa}$ and the salinity dose in the irrigation of $5 \mathrm{dS} \mathrm{m}^{-1}$ (Figure 4). 


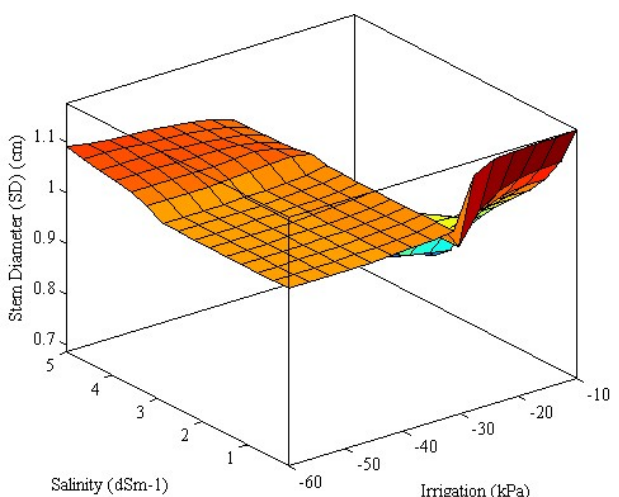

(a)

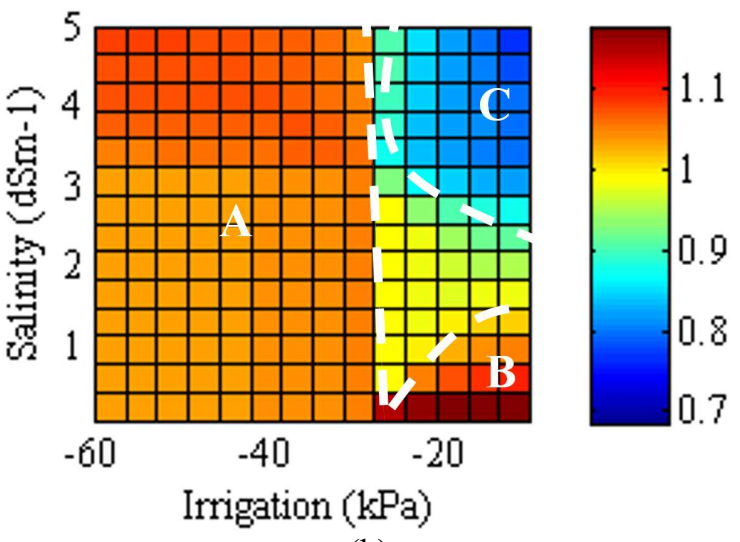

(b)

FIGURE 4. Stem diameter (SD) (in $\mathrm{cm}$ ) for the tomato crop irrigated under water tensions (between -60 and $-10 \mathrm{kPa}$ ) and salinity levels of irrigation (between 0.08 and $5 \mathrm{dS} \mathrm{m}^{-1}$ ). (a) Three-dimensional graph and (b) Contour map.

In Figure $4 b$, it was verified in Region $A$ that regardless of water tension in the soil and salinity doses in irrigation, there was no significant difference in stem diameter. In region $\mathrm{B}$, the highest values of the variable is checked and, in Region C, possibly due to the high salinity of the water, occurred salt accumulation in the soil negatively affecting the stem diameter.

For plants that were irrigated with water whose salinity is $0.08 \mathrm{dS} \mathrm{m}^{-1}$, the water tension in the soil of -30 and $-60 \mathrm{kPa}$ reduced the stem diameter by 15.6 and $16.2 \%$, respectively, compared to tension of $-10 \mathrm{kPa}$ (Silva Junior, 2012). Since Soares et al. (2011) found no significant effect on stem diameter with reduced water availability in

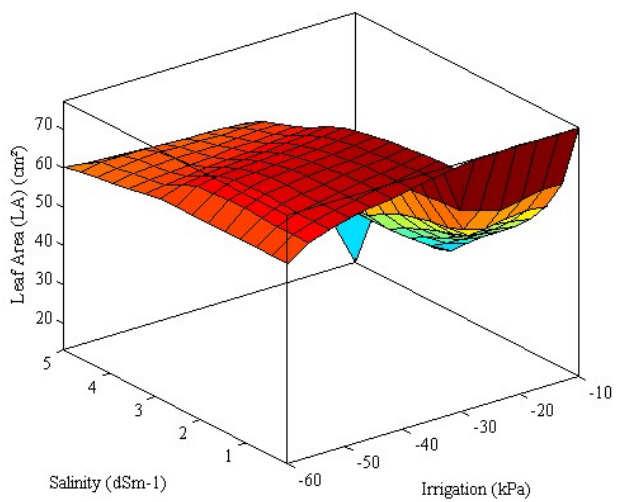

(a) their study and classified this variable as little sensitive to water stress. Furthermore, with regard to salinity, in the study of Gomes et al. (2011) and Guedes et al. (2015), it was noted a small reduction in stem diameter by virtue of its increase, and similarly, Lima et al. (2015) found this effect in eggplant crop.

Leaf area was negatively affected by salinity doses in irrigation between 3 and $5 \mathrm{dS} \mathrm{m}^{-1}$ when subjected to water tension in the soil of $-10 \mathrm{kPa}$, analogous behavior to stem diameter variable. Furthermore, it was found that the leaf area showed the highest values for the treatments of salinity doses in irrigation equal to $0.08 \mathrm{dS} \mathrm{m}^{-1}$ and water tensions on the soil between -30 and $-10 \mathrm{kPa}$ (Figure 5).

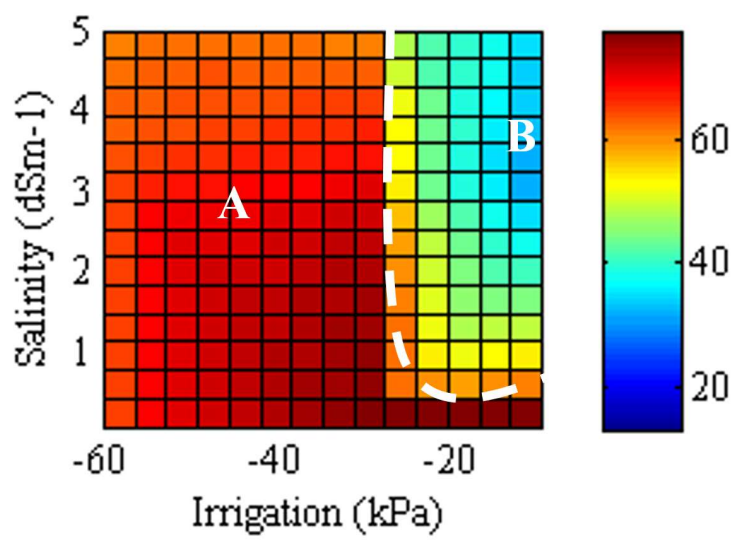

(b)

FIGURE 5. Leaf area (LA) (in $\mathrm{cm}^{2}$ ) for the tomato crop irrigated under water tensions (between -60 and $-10 \mathrm{kPa}$ ) and salinity levels of irrigation (between 0.08 and $5 \mathrm{dS} \mathrm{m}^{-1}$ ). (a) Three-dimensional graph and (b) Contour map.

In Region A (Figure 5b), it was found that the leaf area showed no significant difference between the water tension in the soil of -60 and $-30 \mathrm{kPa}$ for any salinity dose in irrigation. In region $\mathrm{B}$, it was found that the increase in salinity generated the lowest values for leaf area variable, possibly resulting from salt stress on the root environment that causes osmotic and water stress on the plant and consequently the reduction of leaf area (Sousa et al., 2012)

For water tension of $-10 \mathrm{kPa}$ the soil osmotic effect reduces leaf area in 71.6 and $79.6 \%$ when comparing the water salinity doses of 3 and $5 \mathrm{dS} \mathrm{m}^{-1}$, respectively, with a dose of $0.08 \mathrm{dS} \mathrm{m}^{-1}$ (Silva Junior, 2012). The reduction in leaf area under the salinity applied in the irrigation water was also verified by Guedes et al. (2015). Since Soares et al. (2011) reported an increase of $29.45 \%$ in the number of leaves of plants irrigated with depth of $120 \%$ of ETo in relation to the ones submitted to $60 \%$ of ETo in their study.

The green biomass of the tomato crop obtained larger accumulation of soil water tension of $-10 \mathrm{kPa}$ and salinity doses in irrigation between 0.08 and $1 \mathrm{dS} \mathrm{m}^{-1}$. The lowest accumulation occurred to the soil water tension of $-60 \mathrm{kPa}$ and salinity dose in irrigation of $5 \mathrm{dS} \mathrm{m}^{-1}$ (Figure 6). 


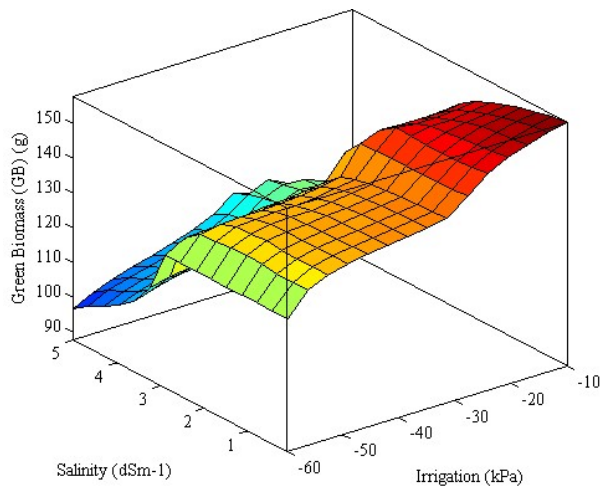

(a)

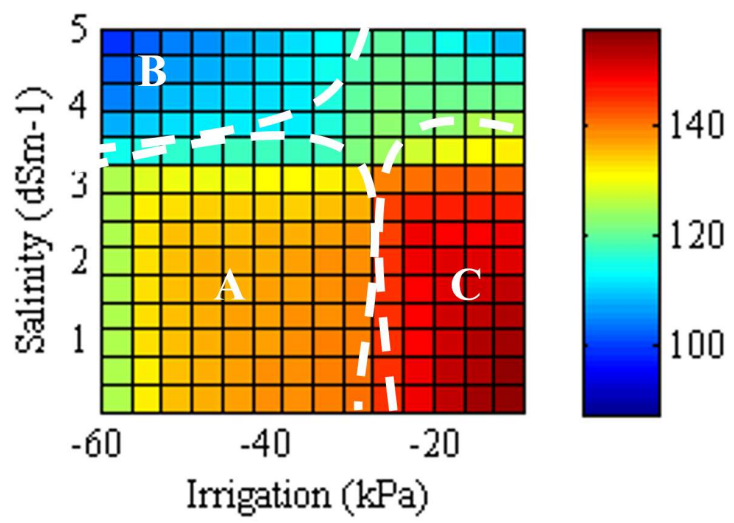

(b)

FIGURE 6. Green Biomass (GB) (in g) for the tomato crop irrigated under water tensions (between -60 and $-10 \mathrm{kPa}$ ) and salinity levels of irrigation (between 0.08 and $5 \mathrm{dS} \mathrm{m}^{-1}$ ). (a) Three-dimensional graph and (b) Contour map.

In the soil water tension between -60 to $-30 \mathrm{kPa}$, no effect was observed in the salinity doses in irrigation between 0 to $3 \mathrm{dS} \mathrm{m}^{-1}$ (Region A) (Figure 6b). As for salinity doses in irrigation between 3 to $5 \mathrm{dS} \mathrm{m}^{-1}$, and considering the same above tensions it was found severe reduction of green biomass (Region B). In Region C, which was kept the water tension in the soil above -30 $\mathrm{kPa}$, the tomato crop had the highest accumulation of biomass to salinity doses in irrigation below $3 \mathrm{dS} \mathrm{m}^{-1}$.

The reduction of tomato green biomass as a result of water stress is observed by several authors (Soares et al., 2012; Morales et al., 2015), this is probably because the "water deficit reduces the turgor pressure and consequently the sap flow by the conducting vessels", as explained Taiz \& Zeiger (2013), this causes "cell

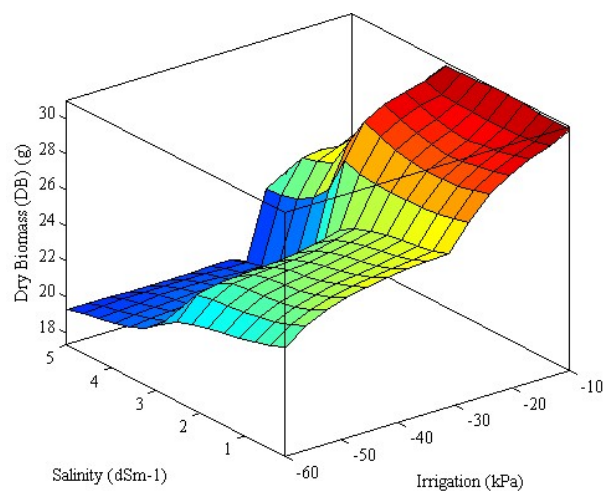

(a) elongation decreases and thus the growth and development of plants". "This provides reductions in leaf expansion, height and diameter of the plants, resulting in loss of plant biomass" (Soares et al., 2012).

The water tension in the soil of $-10 \mathrm{kPa}$ presented significant difference in the production of green biomass among the water salinity doses of 0.08 and $5 \mathrm{dS} \mathrm{m}^{-1}$ of $46.95 \%$ (Silva Junior, 2012). In general, several authors found a negative influence of salinity on the green tomato biomass (Cosme et al., 2011; Malheiros et al., 2012).

It was also inferred values about the dry matter aerial tomato plant that showed similar behavior to the green matter, and the correlation between variables was significant $\left(R^{2}=0,81 ; p<0,001\right)$ (Figure 7).

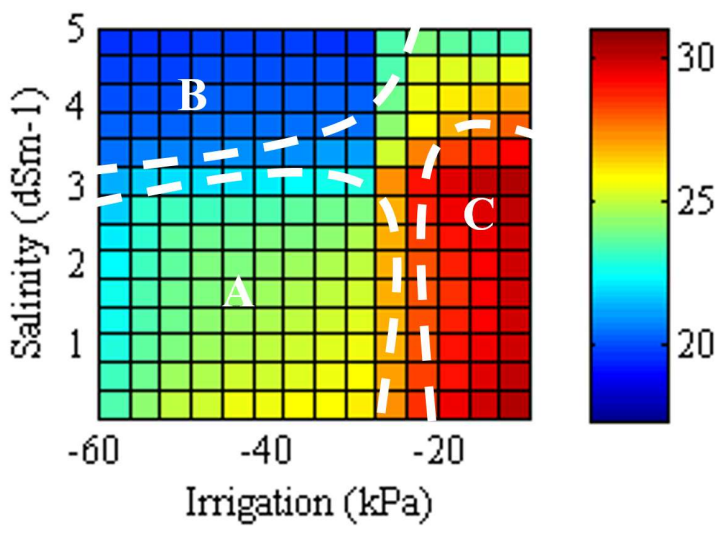

(b)

FIGURE 7. Dry biomass (DB) (in g) for the tomato crop irrigated under water tensions (between -60 and $-10 \mathrm{kPa}$ ) and salinity levels of irrigation (between 0.08 and $5 \mathrm{dS} \mathrm{m}^{-1}$ ). (a) Three-dimensional graph and (b) Contour map.

In Region $\mathrm{A}$, it was noted that both irrigation as the salinity doses do not have severe effects on the variable in question dry biomass (Figure 7b). In Region B there was the lowest accumulation of dry biomass. And in Region C, with water tensions on the soil between -25 to $-10 \mathrm{kPa}$ and salinity doses in irrigation lower than $3 \mathrm{dS} \mathrm{m}^{-1}$, it was found the largest accumulation of dry biomass.

According to Silva Junior (2012), the soil water tension of $-10 \mathrm{kPa}$ also showed significant difference in the production of dry biomass for water salinity doses equal to 0.08 and $5 \mathrm{dS} \mathrm{m}^{-1}$ of $47.14 \%$. The reduction in dry biomass due to the increase of salinity was observed by other authors (Cosme et al., 2011; Gomes et al., 2011; Silva et al., 2013b).
According to Taiz \& Zeiger (2013), "high salinity reduces the rate of metabolic assimilation by plants and the activity of enzymes responsible for respiration and photosynthesis". The same author states that this fact "restricts to obtain energy for the growth and differentiation of cells into tissues, thereby reducing the elongation of the embryonic axis and the dry mass production".

The highest amount of fruits per plant was observed to treatments of soil water tension equal to $-10 \mathrm{kPa}$ regardless of salinity doses in the irrigation. As for the water supply in the soil of $-60 \mathrm{kPa}$ and the salinity dose in irrigation of $0.08 \mathrm{dS} \mathrm{m}^{-1}$, there was a smaller amount of fruits per plant (Figure 8). 


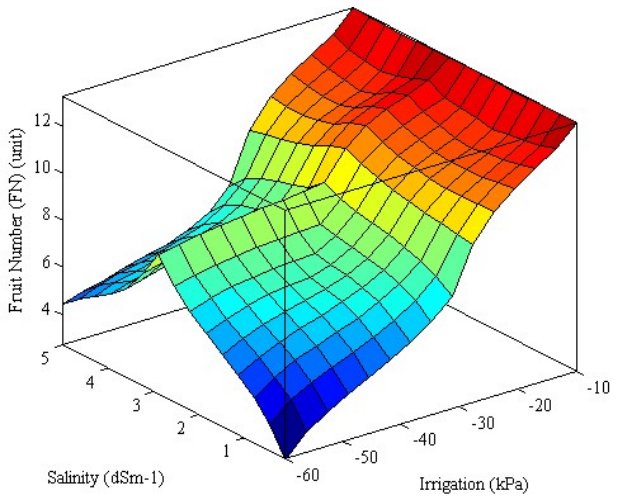

(a)

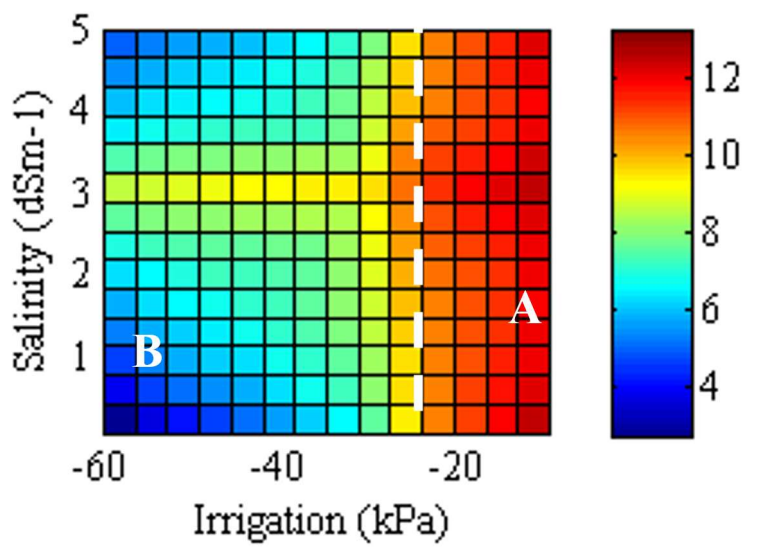

(b)

FIGURE 8. Number of fruits (FN) (in unit) for the tomato crop irrigated under water tensions (between -60 and $-10 \mathrm{kPa}$ ) and salinity levels of irrigation (between 0.08 and $5 \mathrm{dS} \mathrm{m}^{-1}$ ). (a) Three-dimensional graph and (b) Contour map.

In Figure $8 \mathrm{~b}$, it was found that in region $\mathrm{A}$ the managements provided the greatest number of fruits per plant, and water availability was an important factor. It was also found in region $B$ that the drought caused a reduction in the amount of fruits.

Silva Junior (2012) stated that the number of fruits decrease significantly from the water tension in the soil for treatments of salinity doses in irrigation equal to 0.08 or $5 \mathrm{dS} \mathrm{m}^{-1}$, for example, to tension of $-60 \mathrm{kPa}$ compared to tension of $-10 \mathrm{kPa}$, there was a reduction of $84 \%$ in the number of fruits to the water salinity dose of $0.08 \mathrm{dS} \mathrm{m}^{-1}$.

Despite the lack of influence of the water salinity doses on the number of fruits in the experiment analyzed

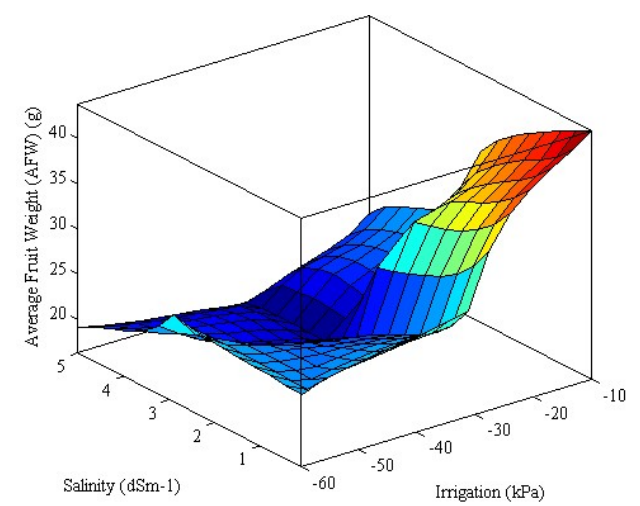

(a) by this study, this effect has been observed by several authors in the tomato crop (Freire et al., 2010; Cosme et al., 2011; Medeiros et al., 2012; Silva et al., 2013b; Guedes et al., 2015) and other Solanaceae, such as eggplant (Oliveira et al., 2014), pepper (Nascimento et al., 2015) and sugar beet (Lima et al., 2015).

Compared with the average weight of fruits, it was found that the highest values occurred when there was irrigated with saline water and was kept at same FC (-10 $\mathrm{kPa}$ ). The lowest values for this variable adopted occurred when water tension in the soil of $-30 \mathrm{kPa}$ and salinity doses in irrigation between 3 and $5 \mathrm{dS} \mathrm{m}^{-1}$ (Figure 9).

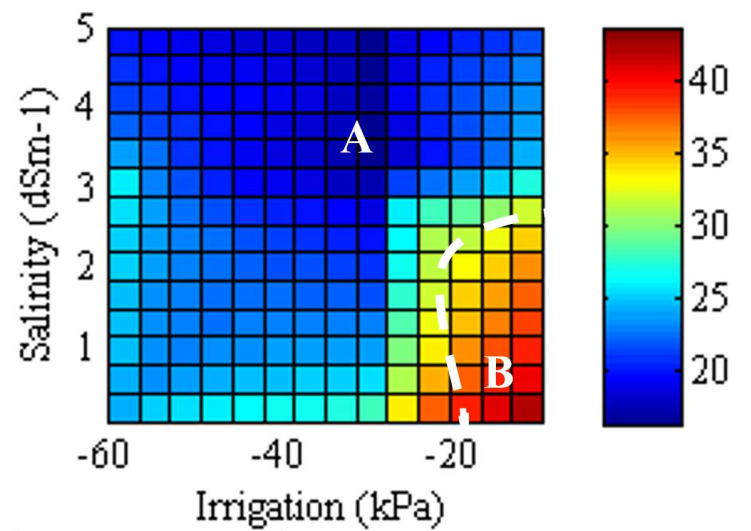

(b)

FIGURE 9. Average fruit weight (AFW) (in g) for the tomato crop irrigated under water tensions (between -60 and $-10 \mathrm{kPa}$ ) and salinity levels of irrigation (between 0.08 and $5 \mathrm{dS} \mathrm{m}^{-1}$ ). (a) Three-dimensional graph and (b) Contour map.

In region A (Figure 9b), it was verified the lowest values for the variable average fruits weight particularly the effects caused by salinity doses in the water. In region $\mathrm{B}$, the water availability for tomato crop provided the highest values for that variable. According to Santana et al. (2010), "the growth or the reduction of the size of a tomato fruit are highly associated with daily increased and reduction of water potential in the plant that is closely related to the amount of water in the soil".

The drought and the saline stress significantly influenced the average fruit weight. The highest value observed in the experiment was $44.84 \mathrm{~g}$ and it was achieved in the treatment $-10 \mathrm{kPa}$ and $0.08 \mathrm{dS} \mathrm{m}^{-1}$ and the lowest value was $15.99 \mathrm{~g}$ obtained in the treatment $-30 \mathrm{kPa}$ and $3 \mathrm{dS} \mathrm{m}^{-1}$ (Silva Junior, 2012). The negative effect of salinity on the average fruit weight was also observed by Oliveira et al. (2014) in eggplant crop.

Finally, we analyzed the percentage of disabled fruits where such deficiency was assessed in relation to the fruits that present apical rot. From the fuzzy modeling, it was verified that this variable presented the highest percentage when the water tension in the soil and the salinity dose in the irrigation used were $-60 \mathrm{kPa}$ and 0.08 $\mathrm{dSm}^{-1}$, respectively. For this salinity dose, the apical rot also presented a high percentage for the water tension in the soil of $-30 \mathrm{kPa}$ and the lowest percentage was verified for the water tension in the soil of $-10 \mathrm{kPa}$ (Figure 10). 


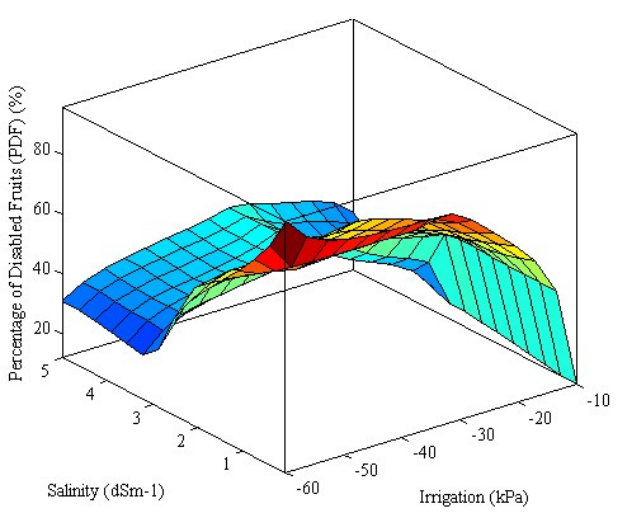

(a)

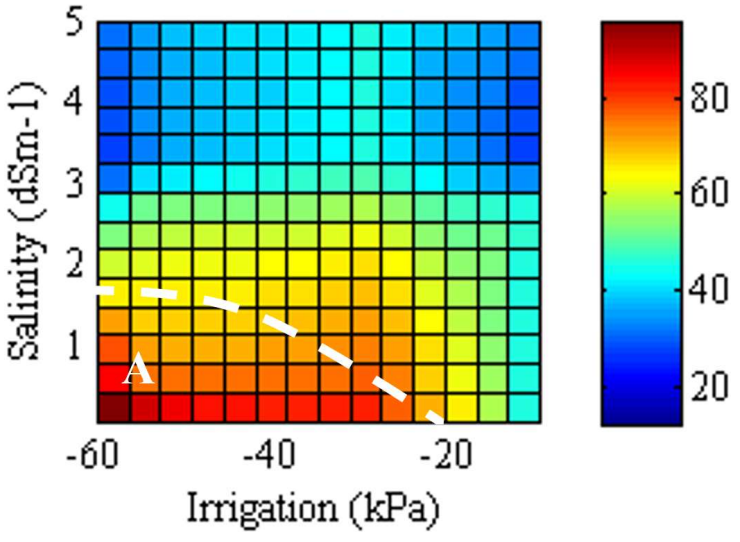

(b)

FIGURE 10. Percentage of Disabled fruit (PDF) (in \%) for the tomato crop irrigated under water tensions (between -60 and -10 $\mathrm{kPa}$ ) and salinity levels of irrigation (between 0.08 and $5 \mathrm{dS} \mathrm{m}^{-1}$ ). (a) Three-dimensional graph and (b) Contour map.

In Figure 10b, it was verified that Region A presents the managements in which the highest percentages of apical rot occurred. According to Silva Junior (2012), the water deficit affected the quality of the fruits and the appearance of apical rot was verified in all treatments, and the lowest value was $9.38 \%$ in the treatment of $-10 \mathrm{kPa}$ and $0.08 \mathrm{dS} \mathrm{m}^{-1}$ and the highest value, $100 \%$, was observed in the treatment of $-60 \mathrm{kPa}$ and $0.08 \mathrm{dS} \mathrm{m}^{-1}$.

"In vegetables, calcium-related imbalances include leaf-edge burning, a common occurrence in lettuce, and apical rot or black background, occurring in tomatoes and peppers" (Arruda Júnior et al., 2011), but Lopes \& Reis (2011), emphasize that "although the main cause of apical rot is attributed to calcium deficiency, insufficient water, even if temporary, contributes significantly to its appearance".

\section{CONCLUSIONS}

The fuzzy modeling allowed analyzing intermediate regions at the experimentation levels and to build other conclusions about the tomato growth and productivity.

All variables studied here showed changes according to the water tension in the soil and / or salinity doses in the irrigation, and that the most favorable results, except for the variable plant height occurred for field capacity irrigation and null water salinity.

For soil water tension between -20 and $-10 \mathrm{kPa}$, there were higher fruit numbers per plant and less incidence of apical rot, and if we consider the salinity levels below $2 \mathrm{dS} \mathrm{m}^{-1}$, we also have the highest average fruits weight, which represents optimal conditions of cultivation. In addition, it is worth mentioning that, for water tension in the soil between -60 and $-30 \mathrm{kPa}$, the salinity doses close to $3 \mathrm{dS} \mathrm{m}^{-1}$ refer to better productivity situations.

Finally, the scientific importance of the method of mathematical modeling established in these works (Part I and II), since it would be possible to apply the method in any other crops, even with different factors from those established here. Faced specifically with the analysis of the tomato experiment performed here, it is emphasized that the present analysis and interpretation also establishes a way of studying the modeling generated. The strategies of defining regions in contour maps and also the way of analyzing these maps in the form of interpretation of the results by fixing one level of the axes and varying the others also establishes a natural way of analyzing the results achieved here.

\section{ACKNOWLEDGEMENTS}

The Authors are grateful for the PhD Program in Agronomy / Irrigation and Drainage (of São Paulo State University, School of Agriculture) and in MSc in Agribusiness and Development (of São Paulo State University, School of Sciences and Engineering) for the scientific contribution made available.

This work was supported by the National Council for Scientific and Technological Development (CNPq) (grant number 313570/2017-5) for the research productivity grant granted to the second author.

\section{REFERENCES}

Arruda Júnior SJ, Bezerra Neto E, Barreto LP, Resende LV (2011) Apical rot and tomato productivity as a function of calcium and ammonium contents. Revista Caatinga 24(4):20-26. DOI:

https://periodicos.ufersa.edu.br/index.php/caatinga/article/ view/1972

Borges SA, Cunha AHN, Silva SMC, Vieira JA, Nascimento AR (2015) Irrigation water quality in the table tomato crop in the municipality of Goianápolis-GO. MultiScience Journal 1(2):74-82.

Cosme CR, Dias NS, Oliveira AM, Oliveira EMM, Sousa Neto ON (2011) Hydroponic tomato production using desalination in the nutrient solution applied at different times. Revista Brasileira de Engenharia Agrícola e Ambiental 15:499-504. DOI: http://dx.doi.org/10.1590/S1415-43662011000500010

Cremasco CP, Gabriel Filho LRA, Cataneo A (2010) Methodology for determination of fuzzy controller pertinence functions for the energy evaluation of poultry industry companies. Energia na Agricultura 25:21-39. DOI: http://dx.doi.org/10.17224/EnergAgric.2010v25n1p21-39

Duarte SN, Dias NS, Teles Filho JF (2007) Recovery of salinized soil due to excess fertilizers in protected environment. Revista Irriga 12(3):422-428. 
Freire ALO, Saraiva VP, Miranda JRP, Bruno GB (2010) Growth, accumulation of ions and production of tomato irrigated with saline water. Semina: Ciências Agrárias 31:1133-1144. DOI: http://dx.doi.org/10.5433/16790359.2010v31n4Sup1p1133

Gabriel Filho LRA, Pigatto GAS, Lourenzani AEBS (2015) Fuzzy rule-based system for evaluation of uncertainty in cassava chain. Engenharia Agrícola 35(2) 350-367. DOI: http://dx.doi.org/10.1590/1809-4430Eng.Agric.v35n2p350-367/2015

Gabriel Filho LRA, Cremasco CP, Putti FF, Chacur MGM (2011) Application of fuzzy logic for the evaluation of livestock slaughtering. Engenharia Agrícola 31(4):813825. DOI: http://dx.doi.org/10.1590/S010069162011000400019

Gabriel Filho LRA, Putti FF, Cremasco CP, Bordin D, Chacur MGM, Gabriel LRA (2016) Software to assess beef cattle body mass through the fuzzy body mass index. Engenharia Agrícola 36(1):179-193. DOI: http://dx.doi.org/10.1590/1809-4430-

Eng.Agric.v36n1p179-193/2016

Giusti E, Marsili-Libelli S (2015) A fuzzy decision support system for irrigation and water conservation in agriculture. Environmental Modelling \& Software 63:73-86. DOI: https://doi.org/10.1016/j.envsoft.2014.09.020

Gomes JWS, Dias NS, Oliveira AM, Blanco FF, Sousa Neto ON (2011) Growth and production of cherry tomatoes in a hydroponic system with desalination waste. Revista Ciência Agronômica 42(4):850-856. DOI: http://www.ccarevista.ufc.br/seer/index.php/ccarevista/arti cle/view/1756

Guedes RAA, Oliveira FA, Alves RC, Medeiros AM, Gomes LP, Costa LP (2015) Irrigation strategies with saline water in the cherry tomato in a protected environment. Revista Brasileira de Engenharia Agrícola Ambiental 19(10):913-919. DOI:

http://dx.doi.org/10.1590/1807-

1929/agriambi.v19n10p913-919.

Kurtener DD, Sukhanov P (2014) Evaluation of agricultural soil resources using fuzzy modeling. Journal of Agricultural Science 6(4):199-204. DOI: http://dx.doi.org/10.5539/jas.v6n4p199.

Lima LA, Oliveira FA, Alves RC, Linhares PSF, Medeiros AMA, Bezerra FMS (2015) Eggplant tolerance to salinity of irrigation water. Revista Agro@mbiente On-line 9(1):27-34. DOI: http://dx.doi.org/10.5327/z19828470201500012202

Lopes CA, Reis A (2011) Diseases of tomato grown under protected environment. Brasília, Embrapa Hortaliças.

Malheiros SMM, Silva EFF, Medeiros PRF, Pedrosa EMR, Rolim MM, Santos AN (2012) Hydroponic cultivation of cherry tomatoes using treated effluent from an ice cream industry. Revista Brasileira de Engenharia Agrícola e Ambiental 16(10):1085-1092. DOI: http://dx.doi.org/10.1590/S1415-43662012001000008.
Mariz-Ponte N, Mendes RJ, Sario S, Melo P, Santos C (2018) Moderate UV-A supplementation benefits tomato seed and seedling invigoration: a contribution to the use of UV in seed technology. Scientia Horticulturae 235:357366. DOI: http://doi.org/10.1016/j.scienta.2018.03.025

Medeiros PRF (2010) Fertigation management in a protected environment aiming the control of salinity for the tomato crop in loamy-clay soil. $\mathrm{PhD}$ Thesis, Piracicaba, University of Sao Paulo, Luiz de Queiroz College of Agriculture.

Medeiros PRF, Duarte SN, Uyeda CA, Silva EFF (2012)

Tolerance of tomato crop to soil salinity in protected environment. Revista Brasileira de Engenharia Agrícola e Ambiental 16:51-55. DOI:

http://dx.doi.org/10.1590/S1415-43662012000100007

Morales RGF, Resende LV, Bordini IC, Galvão AG, Rezende FC (2015) Characterization of tomato under water deficit. Scientia Agraria 16(1):09-17. DOI: http://dx.doi.org/10.5380/rsa.v16i1.41042

Nascimento IB, Medeiros JF, Alves SSV, Lima BLC, Silva JLA (2015) Initial development of pepper culture influenced by salinity of irrigation water in two types of soils. ACSA Agropecuária Científica no Semi-Árido 11(1):37-43. DOI: http://revistas.ufcg.edu.br/acsa/index.php/ACSA/article/view/594

Oliveira FA, Medeiros JF, Alves RC, Linhares PSF, Medeiros AMA, Oliveira MKT (2014) Interaction between irrigation water salinity and nitrogen fertilization in eggplant culture. Revista Brasileira de Engenharia Agrícola e Ambienta 15:480-486. DOI: http://dx.doi.org/10.1590/S1415-43662014000500003

Pereira DF, Bighi CA, Gabriel Filho LRA, Cremasco CPC (2008) Sistema fuzzy para estimativa do bem-estar de matrizes pesadas. Engenharia Agrícola 28(4):624-633. DOI: http://dx.doi.org/10.1590/S010069162008000400002

Putti FF (2015) Analysis of biometric and nutritional indicators of lettuce (Lactuca sativa L.) culture irrigated with magnetically treated water using fuzzy modeling. PhD Thesis, Sao Paulo State University, UNESP.

Putti FF, Kummer ACB, Grassi Filho H, Gabriel Filho LRA, Cremasco CP (2017) Fuzzy modeling on wheat productivity under different doses of sludge and sewage effluent. Engenharia Agrícola 37(6):1103-1115. DOI: http://dx.doi.org/10.1590/1809-4430eng.agric.v37n6p1103-1115/2017

Putti FF, Gabriel Filho LRA, Silva AO, Ludwig R, Gabriel CPC (2014) Fuzzy logic to evaluate vitality of catasetum fimbiratum species (Orchidacea). Revista Irriga 19(3):405413. DOI: http://dx.doi.org/10.15809/irriga.2014v19n3p405 
Santana MJ, Vieira TA, Barreto AC, Cruz OC (2010)

Response of irrigated tomato to levels of soil water replenishment. Revista Irriga 15(4):443-454. DOI: http://irriga.fca.unesp.br/index.php/irriga/article/viewFile/137/84

Silva JM, Ferreira RS, Melo AS, Suassuna JF, Dutra AF, Gomes JP (2013a) Cultivation of tomato in protected environment under different evapotranspiration replacement rates. Revista Brasileira de Engenharia Agrícola e Ambiental 17(1):40-46. DOI: http://dx.doi.org/10.1590/S1415-43662013000100006

Silva Junior JF (2012) Tomato development at different irrigation levels and salinity levels. MSc Dissertation, Sao Paulo State University, UNESP.

Silva PF, Lima CJGS, Barros AC, Silva EM, Duarte SN (2013b) Fertilizing salts and fertigation management in the production of tomato cultivated in a protected environment. Revista Brasileira de Engenharia Agrícola e Ambiental 17:1173-1180. DOI:

http://dx.doi.org/10.1590/S1415-43662013001100007

Soares LAA, Lima GS, Brito MEB, Sá FVS, Silva ECB, Araújo TT (2012) Cultivation of the tomato in the vegetative phase on different irrigation slides in protected environment. Agropecuária Científica no Semi-Árido $8: 38-45$.
Soares LAA, Lima GS, Brito MEB, Araújo TT, Sá FVS (2011) Growth rates of tomato under irrigation slides in protected environment. Revista Verde de Agroecologia e Desenvolvimento Sustentável 6(2):210-217.

Sousa GG, Azevedo BM, Albuquerque AHP, Mesquita JBR, Viana TVA (2012) Agronomic characteristics of peanut under irrigation with salt water in soil with biofertilizers. Revista Agroambiente On-line 6(2):124-132. DOI: http://dx.doi.org/10.18227/1982-8470ragro.v6i2.708

Taiz L, Zeiger E (2013) Plant physiology. Porto Alegre, ArtMed, 954p.

Trani PE, Raij B van (1997) Vegetables. In: Raij B van, Cantarella H, Quaggio JA, Furlani AMC (ed).

Recommendations of fertilization and liming for the State of São Paulo. Campinas, Instituto Agronômico/IAC Foundation.

Van Genuchten MTh (1980) A closed-from equation for predicting the conductivity of unsaturaded solis. Soil Science Society of American Journal 44(5):892-898. DOI: https://doi.org/10.2136/sssaj1980.03615995004400050002x

Zadeh LA (1965) Fuzzy sets. Information and Control 8:338-353. DOI: https://doi.org/10.1016/S00199958(65)90241-X 